\title{
27. CHEMICAL COMPOSITIONS AND Sr ISOTOPES OF DEEP SEA DRILLING PROJECT LEG 61 BASALTS ${ }^{1}$
}

\author{
Naoyuki Fujii, Department of Earth Sciences, Kobe University, Kobe 657, Japan \\ and \\ Kenjii Notsu and Naoki Onuma, Institute of Chemistry, Tsukuba University, Ibaragi 300-31, Japan
}

\begin{abstract}
Sixteen elemental abundances and ${ }^{87} \mathrm{Sr} /{ }^{86} \mathrm{Sr}$ ratio of the Nauru Basin basalt (Cores 75 to 90 : sub-bottom depths 950 $\mathrm{m}$ to $1050 \mathrm{~m}$ ) from Hole $462 \mathrm{~A}$ have been determined by inductively coupled plasma-optical emission spectroscopy and mass spectrometry. The result indicates that the basalt is a new type of oceanic tholeiite, elementally similar to normal mid-oceanic ridge basalts and isotopically similar to oceanic island-type basalts.
\end{abstract}

\section{INTRODUCTION}

Igneous rocks of the volcanic complex recovered at Site 462 in the Nauru Basin suggest a voluminous outpouring of tholeiitic magma, and presumably a filling over of the Nauru Basin by intra-plate volcanism during mid-Cretaceous time (Scientific Party for Leg 61, 1978). This volcanic complex consists of two parts. The upper part (sub-bottom depths between $560 \mathrm{~m}$ and $730 \mathrm{~m}$ ) consists of sills and hyaloclastic sediments, and the lower part (sub-bottom depths from $730 \mathrm{~m}$ to $1068.5 \mathrm{~m}$ ) consists of sills interbedded with pillow-like basalts (Tokuyama and Batiza, this volume).

Tholeiites produced at mid-ocean ridges (MORB) have been recognized as being distinctly different from those of volcanic islands like Hawaii and Iceland (i.e., hot spots), especially in LIL (large-ion-lithophile) trace element abundances and $\mathrm{Sr}$ isotope ratio (e.g., Hofmann and Hart, 1978). There could be many explanations for the differences: disequilibrium partial melting (O'Nions and Pankhurst, 1973); mixing of the two types of magma sources (Schilling, 1973); and heterogeneous mantle material (e.g., O'Nions et al., 1974). Although there are still conflicting models about the chemistry of magma sources in the upper mantle-such as a model assuming a depleted asthenosphere and fertile (or less depleted) mesosphere (Schilling, 1973; Brooks et al., 1976), and another model completely opposite to this (Tatsumoto, 1978; Anderson, in press)-the arguments that the magma source regions in the upper mantle are vertically stratified or regionally heterogeneous in LIL elements and isotopes seem to be currently accepted (Hofmann and Hart, 1978; Kay and Hubbard, 1978; Sun et al., 1979; Wood et al., 1979).

In this paper, we aim to characterize the volcanism producing the two types of sills in the Nauru Basin by comparing the chemical compositions and $\mathrm{Sr}$-isotope ratios of the sills with those of mid-ocean ridge basalts and of oceanic island basalts.

\footnotetext{
${ }^{1}$ Initial Reports of the Deep Sea Drilling Project, Volume 61.
}

\section{ANALYTICAL METHODS AND RESULTS}

All samples analyzed were taken from the coarse-grained parts of the sills and selected as fresh as possible. Determination of 16 elements ( $\mathrm{Al}, \mathrm{Ba}, \mathrm{Ca}, \mathrm{Fe}, \mathrm{K}, \mathrm{Li}, \mathrm{Mg}, \mathrm{Mn}, \mathrm{Na}, \mathrm{P}, \mathrm{Rb}, \mathrm{Sc}, \mathrm{Sr}, \mathrm{Ti}, \mathrm{V}$, and $\mathrm{Y}$ ) was carried out by inductively coupled plasma-optical emission spectroscopy (ICP-OES), using Jarrel-Ash ATOMCOMP Model 975 at the Chemical Analysis Center of the University of Tsukuba. In this analysis, four USGS standard rocks (G-2, GSP-1, AGV-1, and BCR-1) were used as reference standards. Accuracy and precision of the analytical method are estimated to be better than $8 \%$ for all the elements measured. Detailed analytical procedure will be published elsewhere. In addition, $\mathrm{Rb}$ and $\mathrm{Sr}$ contents in three typical samples (462A-30-4, 82-84 cm, 462A-84-3, 22-25 cm, and 462A-90-4, 92-95 $\mathrm{cm}$ ) were determined by the mass spectrometric stable-isotope dilution method.

Strontium was extracted by the conventional cation-exchange technique, and its isotopic composition was measured using a VGMicromass 30GS double-collector-type mass spectrometer. ${ }^{87} \mathrm{Sr} /{ }^{86} \mathrm{Sr}$ ratio in NBS SRM 987 strontium carbonate was between 0.71023 and 0.71032 during the period of analysis. Two standard deviations (2 sigma) of $\mathrm{Sr}$ isotope ratio measurements was less than 0.00005 in all samples analyzed. In order to check the effect of $\mathrm{Sr}$ contamination from sea water, one sample $(462 \mathrm{~A}-84-3,22-25 \mathrm{~cm})$ was leached with hot $6 \mathrm{~N} \mathrm{HCl}$ in a Teflon-sealed vessel at about $110^{\circ} \mathrm{C}$ for one night. ${ }^{87} \mathrm{Sr} /{ }^{86} \mathrm{Sr}$ ratios of original and leached samples were 0.70362 and 0.70368 , respectively, which can be considered identical within the ranges of variations of samples from the lower part of volcanic complex at Hole $462 \mathrm{~A}$ (Cores between 75 and 90 in Table 1). All the results are listed in Table 1.

\section{DISCUSSION}

The chemical composition of the lower sill is remarkably uniform in major and trace elements, as shown in Table 1 (Cores between 75 and 90). The upper sill (three samples from Cores 28 and 30 in Table 1) also shows a homogeneous chemical composition. The two sills are, however, quite different (see also Batiza, this volume; and Tokuyama and Batiza, this volume). The upper sill is enriched in the large cations $(\mathrm{Ba}$ and $\mathrm{Rb}$ ) and high-valency cations ( $\mathrm{Ti}$ and $\mathrm{P}$ ), and has a high $\mathrm{Fe} / \mathrm{Mg}$ ratio compared with the lower sill. These differences suggest that the upper sill is more differentiated than the lower. The differentiation may be a result of fractional crystallization in the magma reservoir or of different degrees of partial melting of the source material. 
Table 1. Sr isotopes and chemical composition of Hole $462 \mathrm{~A}$ basalts. ${ }^{\mathrm{a}}$

\begin{tabular}{|c|c|c|c|c|c|c|c|c|c|c|c|c|c|c|c|c|c|}
\hline $\begin{array}{l}\text { Core-Sec., } \\
\text { Interval (cm) }\end{array}$ & $\begin{array}{l}28-1, \\
22-24^{b}\end{array}$ & $\begin{array}{l}30-4 \\
82-84\end{array}$ & $\begin{array}{l}30-6 \\
85-87\end{array}$ & $\begin{array}{l}75-2, \\
25-28\end{array}$ & $\begin{array}{c}75-5 \\
115-118\end{array}$ & $\begin{array}{l}77-1 \\
25-28\end{array}$ & $\begin{array}{c}77-3 \\
16-19\end{array}$ & $\begin{array}{l}79-5, \\
38-41\end{array}$ & $\begin{array}{l}81-2 \\
73-76\end{array}$ & $\begin{array}{l}84-3 \\
22-25\end{array}$ & $\begin{array}{l}84-4, \\
7-10\end{array}$ & $\begin{array}{l}84-6 \\
20-23\end{array}$ & $\begin{array}{l}85-2 \\
36-39\end{array}$ & $\begin{array}{l}87-1, \\
84-87\end{array}$ & $\begin{array}{l}88-2 \\
67-70\end{array}$ & $\begin{array}{l}89-3 \\
122-125\end{array}$ & $\begin{array}{l}90-4, \\
92-95\end{array}$ \\
\hline $\mathrm{Al}$ & 76200 & 72200 & 73400 & 76300 & 76000 & 76300 & 76500 & 78600 & 74700 & 73800 & 78400 & 74700 & 72900 & 74800 & 73600 & 76700 & 76400 \\
\hline $\mathrm{Ba}$ & 22 & 26 & 21 & 11 & 10 & 10 & 9 & 12 & 14 & 12 & 9 & 10 & 10 & 6 & 15 & 7 & 10 \\
\hline $\mathrm{Ca}$ & 80100 & 76600 & 77300 & 87400 & 86700 & 87600 & 87000 & 88900 & 81700 & 80300 & 81800 & 80600 & 82300 & 82600 & 80600 & 84500 & 82500 \\
\hline $\mathrm{Fe}$ & 98100 & 96500 & 96700 & 84800 & 86500 & 85500 & 84000 & 86800 & 94300 & 95300 & 82600 & 95200 & 91200 & 92400 & 94900 & 97100 & 94500 \\
\hline $\mathrm{K}$ & 900 & 2900 & 2100 & 500 & 500 & 300 & 400 & 500 & 600 & 500 & 500 & 500 & 400 & 400 & 600 & 400 & 400 \\
\hline $\mathrm{Li}$ & 7 & 6 & 7 & 3 & 4 & 3 & 4 & 3 & 4 & 4 & 3 & 5 & 4 & 4 & 5 & 4 & 4 \\
\hline $\mathrm{Mg}$ & 39400 & 40400 & 39100 & 46400 & 46000 & 46100 & 47000 & 45700 & 40300 & 40800 & 43300 & 42400 & 44800 & 43000 & 42100 & 41700 & 41500 \\
\hline Mn & 1630 & 1670 & 1670 & 1440 & 1530 & 1410 & 1370 & 1490 & 1560 & 1570 & 1460 & 1570 & 1550 & 1580 & 1550 & 1800 & 1470 \\
\hline $\mathrm{Na}$ & 18700 & 18500 & 18300 & 17100 & 16800 & 17500 & 17300 & 17500 & 18100 & 17300 & 18500 & 18000 & 17600 & 17800 & 17800 & 18600 & 19000 \\
\hline P & 855 & 858 & 834 & 692 & 695 & 690 & 712 & 725 & 736 & 752 & 685 & 780 & 777 & 743 & 769 & 776 & 800 \\
\hline $\mathrm{Sc}$ & 48 & 48 & 47 & 45 & 45 & 46 & 46 & 46 & 46 & 46 & 47 & 46 & 47 & 46 & 46 & 48 & 48 \\
\hline $\mathrm{Sr}$ & 118 & $\begin{array}{l}107 \\
107^{\mathrm{c}}\end{array}$ & 109 & 93 & 92 & 95 & 95 & 97 & 98 & $\begin{array}{c}98 \\
101^{\mathrm{c}}\end{array}$ & 95 & 95 & 93 & 95 & 95 & 99 & $\begin{array}{l}97 \\
65^{\mathrm{c}}\end{array}$ \\
\hline $\mathrm{Ti}$ & 9450 & 8920 & 9170 & 5980 & 6090 & 6090 & 6130 & 6140 & 7180 & 7250 & 6890 & 7140 & 6900 & 6820 & 7170 & 7380 & 7420 \\
\hline V & 393 & 380 & 378 & 300 & 310 & 310 & 310 & 310 & 350 & 350 & 360 & 350 & 350 & 340 & 350 & 360 & 360 \\
\hline $\begin{array}{l}Y \\
R b^{c}\end{array}$ & 35 & $\begin{array}{r}34 \\
2.75\end{array}$ & 35 & 22 & 24 & 24 & 24 & 24 & 29 & $\begin{array}{r}29 \\
0.46\end{array}$ & 24 & 28 & 26 & 27 & 28 & 30 & $\begin{array}{r}30 \\
0.14\end{array}$ \\
\hline$\frac{{ }^{6 /} \mathrm{Sr}^{0}}{86 \mathrm{Sr}}$ & 0.70377 & 0.70388 & 0.70382 & 0.70366 & 0.70371 & 0.70358 & 0.70370 & 0.70380 & 0.70366 & 0.70362 & 0.70365 & 0.70403 & 0.70366 & 0.70367 & - & 0.70366 & 0.70372 \\
\hline
\end{tabular}

a All values are in ppm except for $\mathrm{Sr}$ isotopic ratios.

bamples for the first three columns (Cores 28 and 30 ) are from the upper sill and others are from the lower sill.

c Values of $\mathrm{Rb}$ and $\mathrm{Sr}$ concentrations are obtained by mass spectrometric isotope dilution.

d Two standard deviations are less than 0.00005 for each sample.

As suggested by seismic profile records, the volcanic complex is distributed throughout the Nauru Basin and is probably related to Cretaceous intra-plate volcanism in adjacent regions (Scientific Party for Leg 61, 1978). The lower sill, which is thicker than the upper sill at Site 462 , could be representative of such volcanism because of its voluminous and less differentiated nature.

In order to clarify the characteristic features of the less differentiated lower sill (hereafter called the Nauru Basin basalt), the chemical compositions of the Nauru Basin basalt, (average of 14 samples from Cores between 75 and 90 in Table 1) a Hawaiian tholeiite (BHVO-1) taken as typical of the hot-spot type of basalt, and a normal-type MORB (average of five samples from normal mid-ocean ridge segments of the Atlantic, Pacific, and Indian oceans, Sun et al., 1979) are listed in Table 2. A primitive mantle composition calculated from the model earth (Ganaphathy and Anders, 1974), assuming chondritic metallic composition $(24.58 \% \mathrm{Fe})$ with $5.3 \% \mathrm{FeS}$ in the earth's core, is also listed in Table 2, as a reference standard.

Figure 1 shows the elemental abundance patterns of three types of the tholeiitic basalts relative to those of the primitive mantle, against ionic radius as abscissa. The similarity of the elemental abundance patterns between the Nauru Basin basalt and normal-type MORB is striking; the Nauru Basin basalt is quite different from the Hawaiian tholeiite of a typical hot-spot type. The patterns suggest that the Nauru Basin basalt is produced by the mid-ocean ridge type volcanism, rather than by the hot-spot type volcanism.

Contrary to the element abundances, the $\mathrm{Sr}$ isotope ratio of the Nauru Basin basalt is similar to that of oceanic island basalts and different from that of normal-type MORB. As shown in Figure $2,{ }^{87} \mathrm{Sr} /{ }^{86} \mathrm{Sr}$ ratio of the Nauru Basin basalt (average value 0.70370 $\pm 0.00011)$ is in the range of various oceanic island basalts (Brooks et al., 1976; Hedge, 1978), but is appreciably higher than that of normal-type MORB (Sun et al., 1979) and does not fit the 1.6-b.y. mantle isochron proposed by Hart and Brooks (1977). Thus, type MORB and various oceanic island basalts, with regard to $\mathrm{Sr}$ isotope ratios and $\mathrm{Rb} / \mathrm{Sr}$ ratios.

The Nauru Basin basalt can be characterized by a higher $\mathrm{Sr}$ isotope ratio and similar elemental abundance patterns relative to normal-type MORB.

It is noted that geochemical and isotope studies require at least two source regions-"depleted" for MORB and "fertile" for hot-spot type basalt-and neither of them can represent primitive mantle, which is not inconsistent with the elemental abundance patterns shown in Figure 1. The characteristics of the Nauru Basin basalt may reflect the regional disequilibrium of $\mathrm{Sr}$ isotopes in the source region where the differentiation processes from primitive mantle or earlier differen-

Table 2. Average composition of tholeiites and primitive mantle (ppm).

\begin{tabular}{lcccc}
\hline Element & $\begin{array}{c}\text { Nauru Basin } \\
\text { Basalt }^{\mathrm{a}}\end{array}$ & $\begin{array}{c}\text { Average } \\
\text { N-MORB }\end{array}$ & $\begin{array}{c}\text { Hawaiian } \\
\text { Tholeite } \\
(\text { BHVO-1) }\end{array}$ & $\begin{array}{c}\text { Primitive } \\
\text { Mantle }^{\mathrm{e}}\end{array}$ \\
\hline $\mathrm{Al}$ & 75700 & 84300 & 72800 & 26300 \\
$\mathrm{Ba}$ & 10 & 8.5 & 132 & 7.6 \\
$\mathrm{Ca}$ & 83900 & 79200 & 80800 & 28700 \\
$\mathrm{Fe}$ & 90400 & 76300 & 86300 & 117900 \\
$\mathrm{~K}$ & 460 & 1010 & 4400 & 250 \\
$\mathrm{Li}$ & 4 & - & $5.7^{\mathrm{d}}$ & 4.0 \\
$\mathrm{Mg}$ & 43700 & 54300 & 44600 & 196600 \\
$\mathrm{Mn}$ & 1530 & 1460 & 1320 & 880 \\
$\mathrm{Na}$ & 17800 & 20500 & 17700 & 2350 \\
$\mathrm{P}$ & 740 & 480 & 1180 & 3200 \\
$\mathrm{Rb}$ & 0.3 & 0.83 & 10.1 & 0.86 \\
$\mathrm{Sc}$ & 46 & 42.4 & 31.6 & 18.0 \\
$\mathrm{Sr}$ & 96 & 109 & 404 & 27.1 \\
$\mathrm{Ti}$ & 6760 & 8020 & 16430 & 1530 \\
$\mathrm{~V}$ & 340 & 265 & 337 & 153 \\
$\mathrm{Y}$ & 26 & 33 & 28 & 4.90 \\
\hline $\mathrm{a}$ & & & &
\end{tabular}

a Average of Cores 75 to 90 at Hole 462A.

b Average of five N-type MORB by Sun et al., (1979).

c Sun et al. (1979), except Li content.

d Kilauea lava (1921), this work.

e Calculated from model earth by Ganaphathy and Anders (1974), assuming that the core is the mixture of metallic iron (Fe:Ni:Co $=24.58 \%: 2.39 \%: 0.13 \%$ ) of chondrite and $5.30 \%$ FeS. 


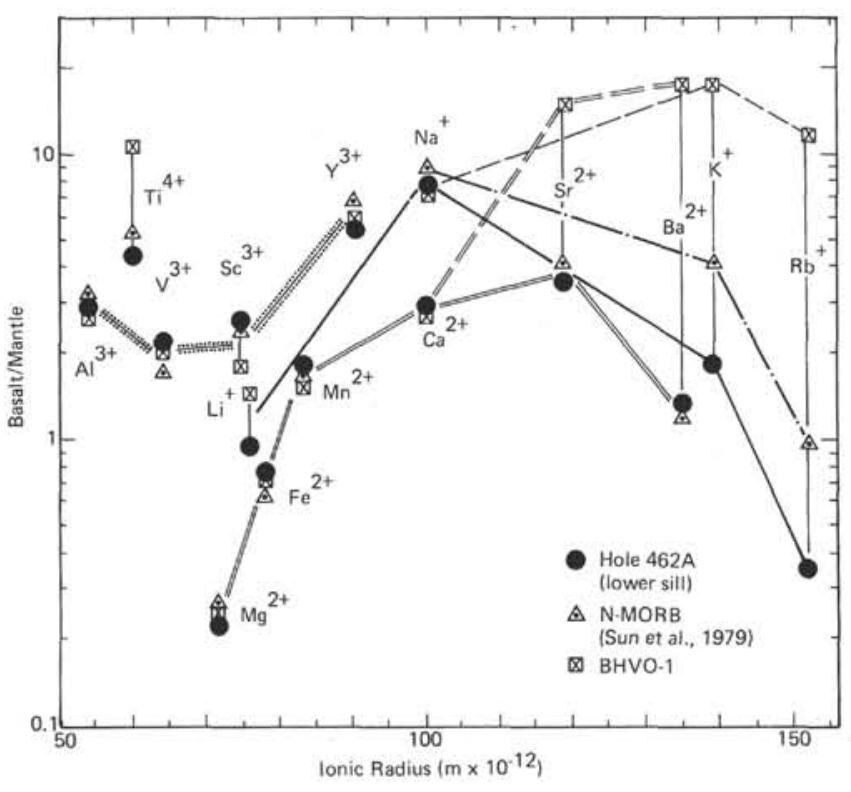

Figure 1. Elemental abundances of tholeiites (from the Nauru Basin [the lower sill of Hole 462A], Hawaii Islands [BHVO-1], and $\mathrm{N}$-type MORB [Sun et al., 1979]) relative to primitive mantle composition, against ionic radius.

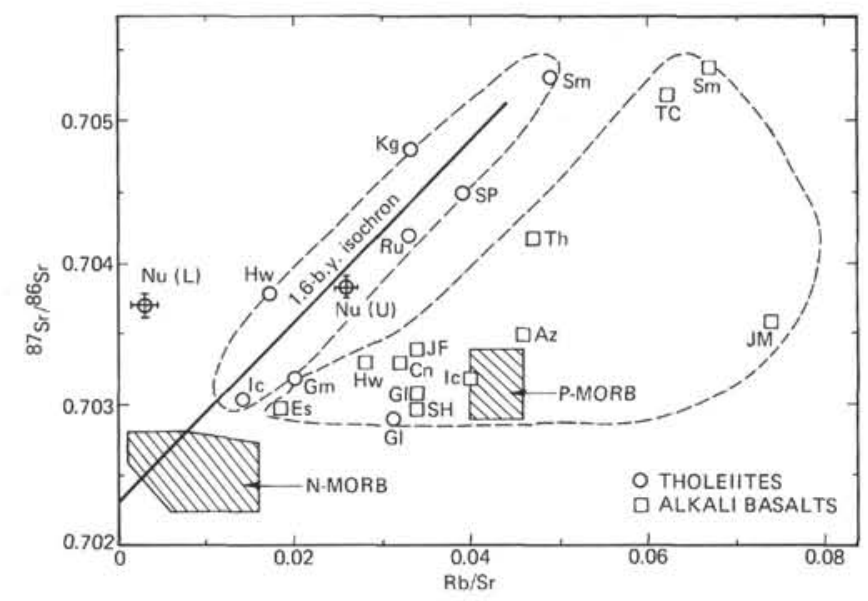

Figure $2 .{ }^{87} \mathrm{Sr} /{ }^{86} \mathrm{Sr}$ versus $\mathrm{Rb} / \mathrm{Sr}$ plots of oceanic basalts. Data are from Brooks et al. (1976), Hedge (1978), Sun et al. (1979), and this study. The 1.6-b.y. mantle isochron proposed by Hart and Brooks (1977) is also shown. N- and P-MORB indicated by hachured regions are normal type and plume type mid-ocean ridge basalts, respectively (Sun et al., 1979). Az: Azores, Cn: Canary, Es: Easter, Gl: Galapagos, Gm: Gambier, Hw: Hawaii Islands, Ic: Iceland, JF: Juan Fernandez, JM: Jan Mayen, Kg: Kerguelen, Nu (U) and (L): Nauru Basin (upper and lower sills), Ru: Reunion, SH: St. Helena, Sm: Samor, SP: St. Pauls, TC: Tristan Da Cunha, Th: Tahiti.

tiated mantle are still continuing (Hofmann and Hart, 1978). It seems likely that the Nauru Basin basalt is formed from the depleted mantle left by the volcanism producing enriched oceanic island basalts in the adjacent area, and the source region of this volcanism has uniform ${ }^{87} \mathrm{Sr} /{ }^{86} \mathrm{Sr}$ ratio similar to ${ }^{87} \mathrm{Sr} /{ }^{86} \mathrm{Sr}$ ratios of oceanic islands in the central and southern Pacific Basin (Hedge, 1978).
Because we could not determine age by the $\mathrm{Rb}-\mathrm{Sr}$ internal isochron method, it is possible that the Nauru Basin basalt was formed at the mid-ocean ridge during the Jurassic. Even if the Nauru Basin basalt was not produced at the mid-ocean ridge in Jurassic time, but rather outpoured by off-ridge intra-plate volcanism (Scientific party for Leg 61, 1978), the voluminous, non-edifice-building magma, chemically similar to normal-type MORB magma would be formed by a process similar to that at the mid-ocean ridge.

Some other processes, such as sea-water contamination in the magma reservoir of the Nauru Basin basalt, or mixing of the two types of magma derived from chemically stratified upper mantle, cannot be ruled out at this moment.

It is important to clarify the age of the sill complex at the Nauru Basin and adjacent area, the extent of "Cretaceous" intra-plate volcanism in the Pacific Basin, and the processes which occurred in an evolving upper mantle to produce the heterogeneity of the observed geochemical characteristics in the various oceanic basalts.

\section{ACKNOWLEDGMENT}

Comments and suggestions offered by $\mathrm{H}$. Tokuyama were valuable. We acknowledge $R$. Batiza, K. Seifert, and H. Tokuyama for kindly providing us the chemical data before publication. Our thanks also go to Mr. M. Hirano for his technical assistance in ICPOES analysis. One of us (N.F.) is particularly grateful to the co-chiefs and other scientists of Leg 61 for providing him a chance to join the extended part of Leg 61. We thank K. Ito and I. Kaneoka for the critical and constructive reviews. This work was supported in part by grants from the Ministry of Education in Japan. We are also grateful to Ms. J. Asakura for typing the manuscript.

\section{REFERENCES}

Anderson, D. L., in press. Irreversible differentiation of the earth and plate tectonics. In Hanks, T. (Ed.), Proceedings of the Conference on the Magnitude of Deviatoric Stresses in the Earth's Crust and Upper Mantle. J. Geophys. Res., Special Issue.

Brooks, C., Hart, S. R., Hofmann, A., et al., 1976. Rb-Sr mantle isochron from oceanic regions. Earth. Planet, Sci. Lett., 32:51-61.

Ganaphathy, R., and Anders, E., 1974. Bulk compositions of the moon and earth, estimated from meteorites. Proc. Fifth Lunar Sci. Conf: Geochim. Cosmochim. Acta, Suppl. 5, 2:1181-1206.

Hart, S. R., and Brooks, C., 1977. The geochemistry and evolution of early Precambrian mantle. Contrib. Mineral. Petrol., 61:109-128.

Hedge, C. E., 1978. Strontium isotopes in basalts from the Pacific Ocean Basin. Earth Planet. Sci. Lett., 38:88-94.

Hofmann, A. W., and Hart, S. R., 1978. An assessment of local and regional isotopic equilibrium in the mantle. Earth Planet. Sci. Lett., 38:44-62.

Kay, R. W., and Hubbard, N. J., 1978. Trace elements in oceanic ridge basalts. Earth Planet. Sci. Lett., 38:95-116.

O'Nions, R. K., and Pankhurst, R. J., 1973. Secular variations in the Sr-isotope composition of Icelandic volcanic rocks. Earth Planet. Sci. Lett., 21:13-21.

O'Nions, R. K., Pankhurst, R. J., and Gronvold, K., 1974. Nature and development of basalt magma sources beneath Iceland and Reykjanes Ridge. J. Petrol., 17:315-338.

Scientific Party for Leg 61, 1978. Volcanic complex found in the westcentral Pacific. Geotimes, 1978, 21-24.

Schilling, J.-G., 1973. Iceland mantle plume: Geochemical study of they Reykjanes Ridge. Nature, 242:565-571.

Sun, S.-S., Nesbitt, R. W., and Sharaskin, A. Y., 1979. Geochemical characteristics of mid-ocean ridge basalts. Earth Planet. Sci. Lett., 44:119-138. 
Tatsumoto, M., 1978. Isotopic composition of lead in oceanic basalt and its implication to mantle evolution. Earth Planet. Sci. Lett., 38:63-87,
Wood, D. A., Tarney, J., Varet, J., et al., 1979. Geochemistry of basalts drilled in the North Atlantic by IPOD Leg 49: Implications for mantle heterogeneity. Earth Planet. Sci. Lett., 42:77-79. 